\title{
降伏機構分離型鉄筋コンクリート造耐震壁における 壁脚部スリップ定量評価方法 \\ EVALUATION METHOD OF SLIP PHENOMENA FOR SHEAR WALLS WITH HING ISOLATED STRUCTURAL SYSTEM
}

\author{
都祭弘幸*1, 平石久廣*2 \\ Hiroyuki TOMATSURI and Hisahiro HIRAISHI
}

\begin{abstract}
The test results of the hinge isolated shear walls (called as HISS RC walls) showed slip phenomena at the wall in the large deformation range after flexural yielding. If their slip phenomena had been restricted, they, obviously, could have had stable energy absorption capacity. This paper reports the details of slip phenomena in terms of load-displacement relationships and vertical displacements at the wall bottom. Considering dowel behavior, the slip stiffness at the load zero can be modeled using pile registration formulae. The ratio of the flexural stiffness to the slip stiffness is an effective index to assess the effect of slip phenomena after flexural yielding on energy absorption characteristics.
\end{abstract}

\section{Keywords : Shear wall, Hinge isolated system, Un-bonded flexural reinforcing bars, Slip phenomena} 耐震壁、降伏機構分離、接合部筋、スリップ現象

\section{1.はじめに}

降伏機構分離とは、曲げ降伏ヒンジが想定される境界部において 部材内における付着を無くした接合部筋で接合され、同ヒンジ部の せん断抵抗機構（トラス機構）を成立させるために接合部筋と平行 に曲げ補強筋を配筋した構造である。この機構を用いた梁部材や柱 部材に関する研究が実施され、現在までにその優れた構造性能が確 認されている1) 5)。

筆者らは、曲げ降伏型連層耐震壁に降伏機構分離型の配筋方法を 適用した場合の基本耐震性能を把握するために、中高層RC建物を想 定した縮尺約 $1 / 3$ の 3 層連層耐震壁の構造実験を行った $\left.{ }^{6)}, 7\right) 。$

その結果、降伏機構分離型連層耐震壁において曲げ降伏後にエネ ルギー吸収能力の高い安定した復元力特性を保有させるためには、 繰返し載加における全体変形量に占めるスリップ変形量を増加させ ないことが重要であることが確認された。また、そのスリップ変形 量を抑制するためには、壁脚部接合面における軸方向鉄筋量・ダボ 筋量や軸方向力とスリップ変形・せん断剛性との関係を定量的に評 価する手法が不可欠であることが認識された。

曲げ降伏後の部材端部におけるスリップ性状や強度・メカニズム に関する研究は、一体打ちと同等の部材性能を求められるプレキャ スト (以下、PCa と略す) 構造に関するものがほとんどである。望月ら は壁式PCa鉛直接合部のせん断抵抗機構を示し設計式を提案してい $3^{8)}$ 。槇谷らはコッターの無いPCa部材接合部に関する実験的研究か らせん断耐力式を提案している $\left.{ }^{9)} 11\right)$ 。中野らは多数の実験を実施し PCa部材接合面の累加耐力評価法を提案している ${ }^{12), 13)}$ 。
一方、一体打ちの接合部に関する研究では、衣笠らによる梁部材 の曲げ降伏後の大変形領域における繰返し載荷に起因するスリップ 現象のメカニズムの提案 ${ }^{14)}$ や塩原らによるスリップ性状を考慮した 梁部材の復元力特性の提案 ${ }^{15)}$ などがある。

本論文では、これまでの4体の降伏機構分離型連層耐震壁に関する 実験研究結果から壁脚部の変形性状を分析し、曲げ降伏後のスリッ プ破壞の定量的な評価手法を提案した。また、同提案により降伏機 構分離型耐震壁におけるスリップ破壊抑制の可能性を示した。

\section{2. 降伏機構分離型耐震壁実験概要}

本論文で検討を行った降伏機構分離型耐震壁の実験の評価につい ては文献6)及び7）を参考にされたい。以下では本論文に関わる事項 の概要を記す。

試験体の形状寸法は4体全て同一であり、載荷は図1に示寸装置を 用いて軸力を一定に保持した状態で正負交番の繰返し加力を行った これら4体の降伏機構分離型耐震壁は、ヒンジ領域を1階分の高さと し、この領域における鉄筋の平均歪 $5 \%$ 、曲げ降伏後頂部変形角 $2 \%$ ま で良好な変形性能を保有することを計画した。

4体の試験体のパラメータは、ヒンジ領域となる耐震壁付帯柱の降 伏機構分離型配筋方法及び作用軸力である (表1参照)。No. 1、No. 2、 No. 4の耐震壁1階ヒンジ領域計画部の配筋図を図2に示し、No. 1〜 No. 4の柱断面配筋方法を図3に示す。No.3はNo. 2の配筋にスリップ変 形を抑制する目的で柱下部の断面中央部にダボ筋を追加で配したも のである。図中に記載する接合部筋とは基礎に定着され1階側柱内の
*1 五洋建設(株建築エンジニアリング部 工修

*2 明治大学理工学部建築学科 教授. 工博 (独立行政法人建築研究所 客員研究員)
Architectural Division, Penta-Ocean Construction Co., Ltd., M. Phil. Prof., Dept. of Architecture, Science and Technology, Meiji Univ., Dr. Eng. (Visiting Research Fellow, Building Research Institute) 


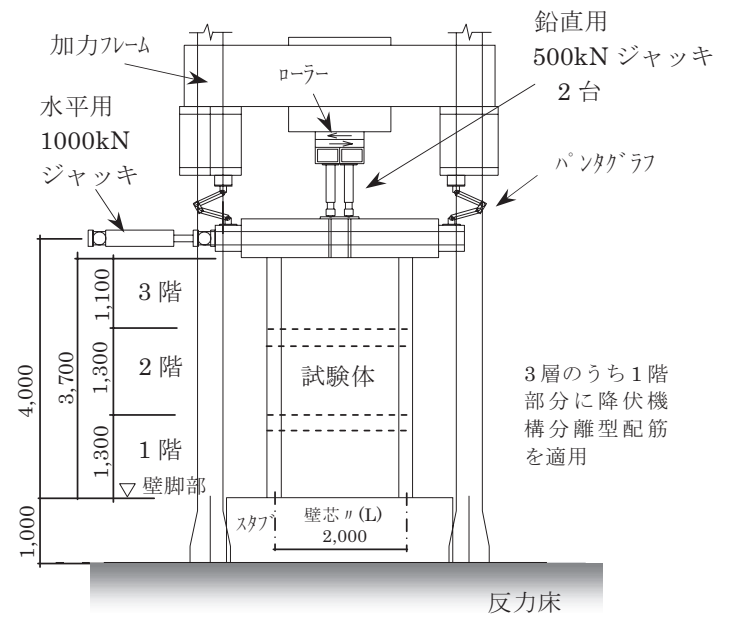

図 1 加力装置 $\cdot$ 試験体形状

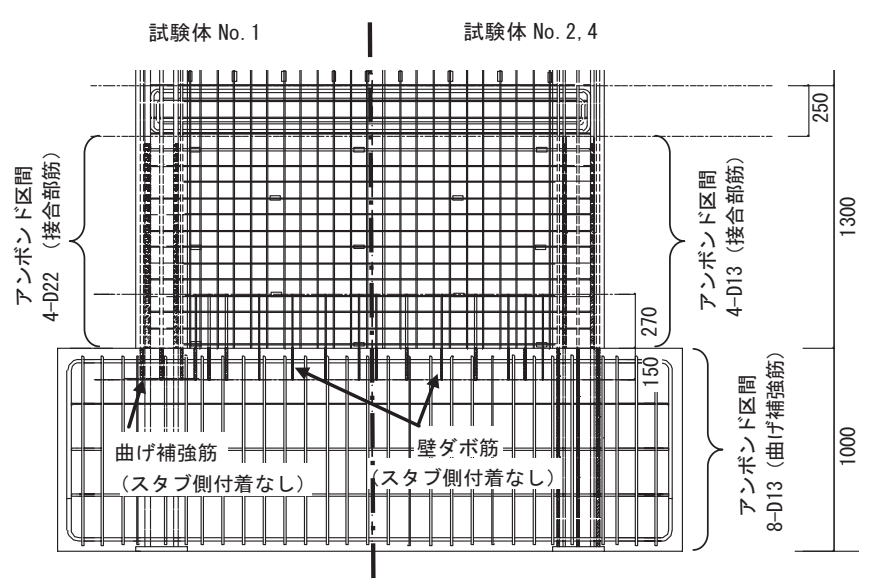

図 2 試験体配筋図
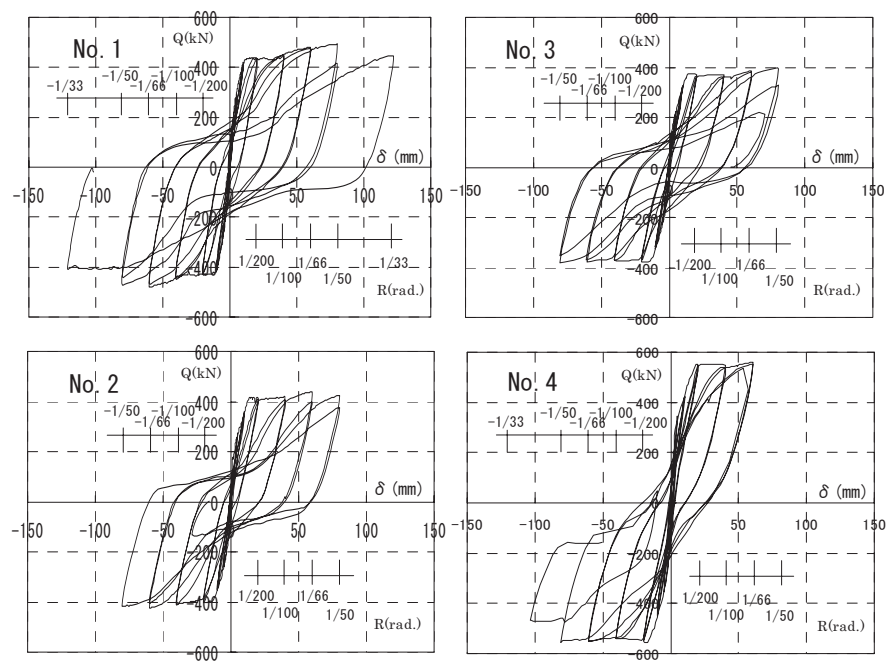

図 4 荷重変形曲線

付着を切った鉄筋であり、曲げ補強筋とは従来の柱筋を呼ぶ。

降伏機構分離型而震壁の配筋方法は、接合部筋方式と接合部筋 ・ 曲げ補強筋併用方式2つに大別される。接合部筋方式(No. 1) は柱内部 に配した4本の接合部筋のみが曲げに対して有効であり、1階部分に アンボンド区間を有する。No, 1の曲げ補強筋はダボ筋としての効果 を持たせるため基礎内に延長されているがコンクリートとの付着は 無い。接合部筋・曲げ補強筋併用方式 (No. 2、3,4) は、接合部筋・曲 げ補強筋全ての鉄筋が壁脚部の曲げ抵抗に有効となるように配筋す
表 1 試験体一覽

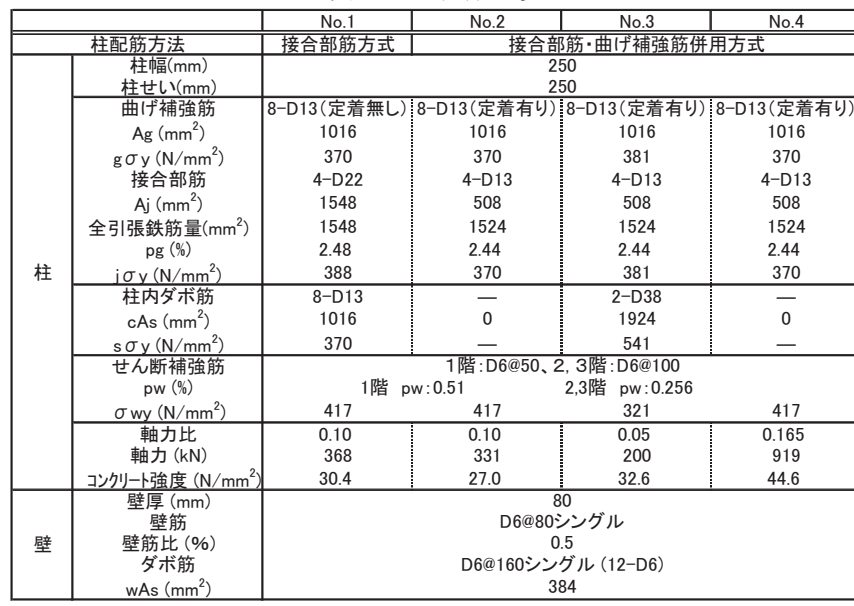

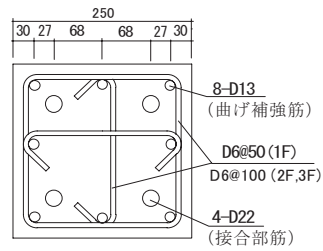

No. 1 柱断面図

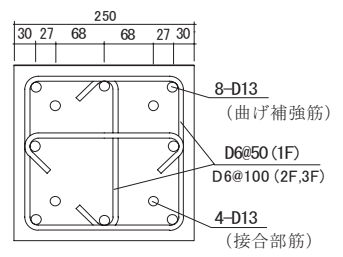

No. 2, No. 4 柱断面図

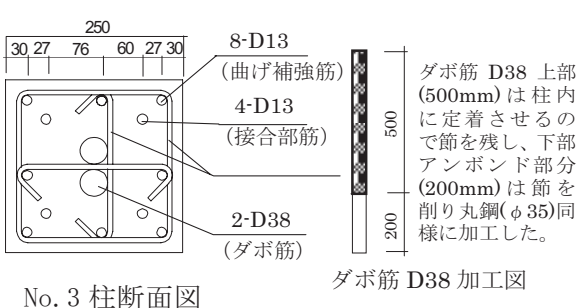

No. 3 柱断面図

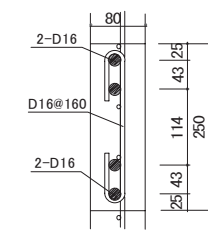

梁断面図 (共通)
図 3 柱配筋方法

る方法である。この場合の曲げ補強筋は基礎内の付着を切り基礎底 面で定着されている。図4に各試験体の荷重変形曲線を示寸。実験か ら降伏機構分離型RC造耐震壁について以下のことが確認された。

1) 壁脚部のスリップ変形は、 $\mathrm{R}=1 / 100$ 以降の変形領域で増大し、 その変形量は降伏機構分離の配筋方法や軸方向力によって異 なる。

2) 曲げ降伏後に荷重変形曲線に影響を及ぼすスリップ現象は、 繰返し載荷において除荷後に逆方向の水平荷重が作用したと きに発生する。このスリップ変形が生じる要因は、伸びた引 張側主筋が除荷しても戻らないため、逆方向の水平荷重が作 用したときに圧縮側・引張側ともに浮上った状態となり壁脚 部におけるせん断抵抗が軸方向筋の水平剛性だけになるため である。

3 ）ダボ筋はスリップ変形抑制に有効である。ただし、R=1/100で ダボ筋が壁脚部コンクリート境界面で曲げ降伏すると全体変 形に占めるスリップ変形量は増加し、抑制効果は低下する。

4 ）軸方向力が高い方がスリップ変形を抑えることができる。こ の理由は、水平荷重ゼロから逆方向載荷時の圧縮側・引張柱 の浮上り量が小さくなるためだと考えられる。

\section{3. 降伏機構分離型耐震壁のスリップ現象}

降伏機構分離型耐震壁の場合、柱に配筋した主筋はコンクリート 
との付着がないので、ヒンジが想定される領域での曲げひび割れ発 生が抑制できる替わりに、壁脚部でのひび割れ幅が大きくなる。言 い換えると、壁脚部のひび割れに集約されるので壁板の曲げひび割 れが少なくなると言える。降伏機構分離型耐震壁には壁脚部のひび 割れが大きくなることがスリップ変形を誘発する原因とならないよ うにスリップ現象を抑制することが求められる。

図5に全体変形量増分に対する壁脚部のスリップ変形が占める割 合の推移を示す。壁脚部スリップとは耐震壁中央脚部高さ $125 \mathrm{~mm}$ 位置 (1階高さ $1,300 \mathrm{~mm}$ の約 $1 / 10)$ における水平変位である。この割合は、 柱配筋方法やダボ筋の有無、軸方向力の大きさによって異なるが、 軸方向力の大きいNo. 4を除き軸方向筋の降伏が始まるR=1/200の繰 り返し載荷から増加する傾向がある。図5からスリップ現象の抑制に は軸方向力を大きくすることが効果的であるように思える。しかし、 曲げ降伏後、回転中心となる圧縮側柱脚部の圧壊が早まり変形性能 が低下寸ることが報告されている16)ので、スリップ現象を抑制する 手段として適しているとは言いがたい。

降伏機構分離型耐震壁の等価粘性減衰定 (以降heq と呼ぶ) は 5 〜 $25 \%$ 程度であり、一般的な耐震壁同様に変形角の増加に伴いheq も増 加する。文献17)では曲げ降伏型耐震壁のheqを塑性率との関係で分 析し、塑性率6以上 (耐震壁の降伏を $\mathrm{R}=1 / 400$ と寸ると $\mathrm{R}=1 / 66$ 以降とな る)の変形増分に対して初期サイクルで16２0\%弱、2サイクル目以降 では約80\%低下し15\%弱となり、変形が増大しても15\%を超える実験結 果は少ないことを示している。それに対して、降伏機構分離型耐震 壁の場合、 $\mathrm{R}=1 / 100$ (塑性率4相当)の履歴で概ね 2 heqは $20 \%$ まで上昇し、 繰返しでも $15 \%$ 程度のheqを保持することができる。これらのことか ら降伏機構分離型耐震壁は、一般的な耐震壁に比べて塑性化しても 安定したエネルギー吸収性能を有する構造であると考えられる。

スリップ現象をさらに詳細に分析するために図6にNo.1からNo. 4 の $\mathrm{R}=1 / 100$ と $\mathrm{R}=1 / 66$ における荷重一頂部変形関係を示す。図6の縦軸 は各試験体のR=1/100，1/66サイクルにおける最大荷重で除した比 とし、横軸は加力点頂部の部材角である。図7にNo. 1 とNo. 3のR=1/50 サイクルの荷重一頂部変形関係を示寸。また、図8にNo.1からNo. 4 の $\mathrm{R}=1 / 66$ サイクルにおける壁脚部鉛直变位 $\left(\delta_{\mathrm{v}}\right)$ 一頂部部材角 $(\mathrm{R})$ 関 係を、図 9 に $\mathrm{R}=1 / 66$ サイクルにおける壁脚部鉛直変位 $\left(\delta_{\mathrm{v}}\right)$ 一壁脚部 スリップ変形 $(\delta \mathrm{s})$ 関係を示す。ここで、壁脚部鉛直変位とは図 10 に示す両側の付帯柱脚部高さ $250 \mathrm{~mm}$ の伸びを正とする鉛直変位の平 均である。図6,8,9中の はR=1/66のサイクルにおいて壁脚部鉛直変 位が最小となる点を表し、 $\nabla$ は水平力荷重ゼロの点を示している。

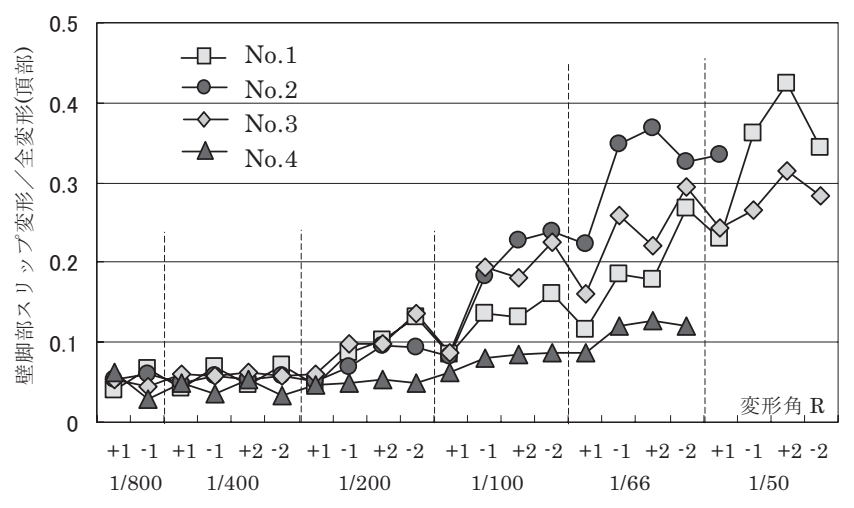

図 5 壁脚部スリップ変形量の割合
図5ではR=1/100のサイクル繰返しによるスリップ変形量の増加が 見られるが、図6の荷重変形関係では顕著なスリップ現象は見られな い。しかし、R=1/66のサイクルでは、No.2の繰返し載荷時にスリッ プ変形量が急激に増加し、図6のNo. 2のように変形 0 近傍において荷 重増が無く水平変形だけが増加する、せん断剛性が著しく低下した 現象が出現する。そのループにおける壁脚部スリップ変形／全変形 量 (図5参照)の割合は、 $\mathrm{R}=1 / 66$ 正側 1 回目 0.22 から負側 1 回目以降 0.33〜0.35に増加する。図7に示すようにNo. 1 とNo. 3でもR=1/50のサ イクルではスリップ現象が現れ、スリップ変形／全変形量は 0.3 を超 えている。これらのスリップ変形/全変形量が 0.3 を超える変形段階 におけるheqは低下寸る傾向が確認された。これは全体変形量に占め るスリップ変形量の割合が増加したために履歴エネルギー面積が減 少したことに起因すると考えられる。

図8,9に着目寸ると、現象に共通点が見られる。それは、各サイク ルのピーク時 (記号(3), (6), (9), (12) に壁脚部鉛直変位は最大となるこ と、繰返しによりピーク時のスリップ変形量は大きくなること、壁 脚部鉛直変位が最小となる点 (記号○; (2), (5), 8), (11) は水平荷重ゼ口 時 (記号 $\nabla ;$; (4), (7), (10), (13)) ではなく逆方向に載荷・変形した後に現れ ることである。壁脚部鉛直変位も壁脚部スリップ変形も軸力が高い No. 4を除き、繰返しピーク点からの荷重除荷による戻り量は小さい。 また、スリップ変形量が大きいほど(No. 2)、ピーク時の壁脚部鉛直 変位が小さく、その変位が戻る勾配は平坦である。

壁脚部鉛直変位が最小となる点 $(\mathbf{O})$ を荷重変形曲線上 (図6)で見 ると、耐震壁の剛性が変化する点に相当していることが分かる。壁 脚部鉛直変位が最小になるまでスリップ変形が卓越する剛性が低下 した状態となり、○点以降はスリップ変形より曲げ変形が卓越する 状態となる。

降伏機構分離型耐震壁では、壁脚部鉛直変位の累積に伴い脚部ひ び割れ面が開き耐震壁全体が浮上った状態となるのでコンクリート の噛み合いによる摩擦抵抗がなくなるため、壁脚部におけるせん断 剛性は、軸方向鉄筋で決定されることになる。部材角の増大に伴い 壁脚部鉛直変位が大きくなっても壁脚部のせん断剛性が回転剛性を 上回っている状態であればスリップ現象は抑制できると推測できる。

壁脚部のせん断剛性を定量的に評価するためには、壁脚部の鉛直 変位を定量的に推定することが求められる。さらに、水平力ゼ口時 における壁脚部のせん断剛性と回転剛性を比較することにより曲げ 降伏後のスリップ現象の危険性を定量的に評価することが可能であ ると考えられる。

\section{4. 壁脚部鉛直変位の推定}

水平力ゼロ時におけるせん断剛性評価に用いる壁脚部鉛直変位は、 図10に示したように圧縮側・引張側の鉛直変位の平均を考える。こ の鉛直変位の推移を分析するために、図11にNo.1からNo.4各試験体 のR=1/400から $1 / 66$ サイクルのピーク時と水平荷重ゼロ時における 壁脚部鉛直変位量 $\left(\delta_{V}\right)$ を示す。ピーク時・水平荷重ゼロ時の $\delta_{V}$ とも に、その推移は頂部変形角の増大に応じて増加する。軸力の高いNo. 4 の $\delta_{V}$ ではピーク時変位量は他の試験体と大きな差はないが、除荷に より $\delta_{V}$ が大きく戻ることが分かる。また水平荷重ゼ口時にNo. 1, 2, 3 ではR=1/400のサイクルまで、No. 4 はR $=1 / 200$ まで $\delta_{V} \fallingdotseq 0 \mathrm{~mm}$ となるこ とが分かる。 

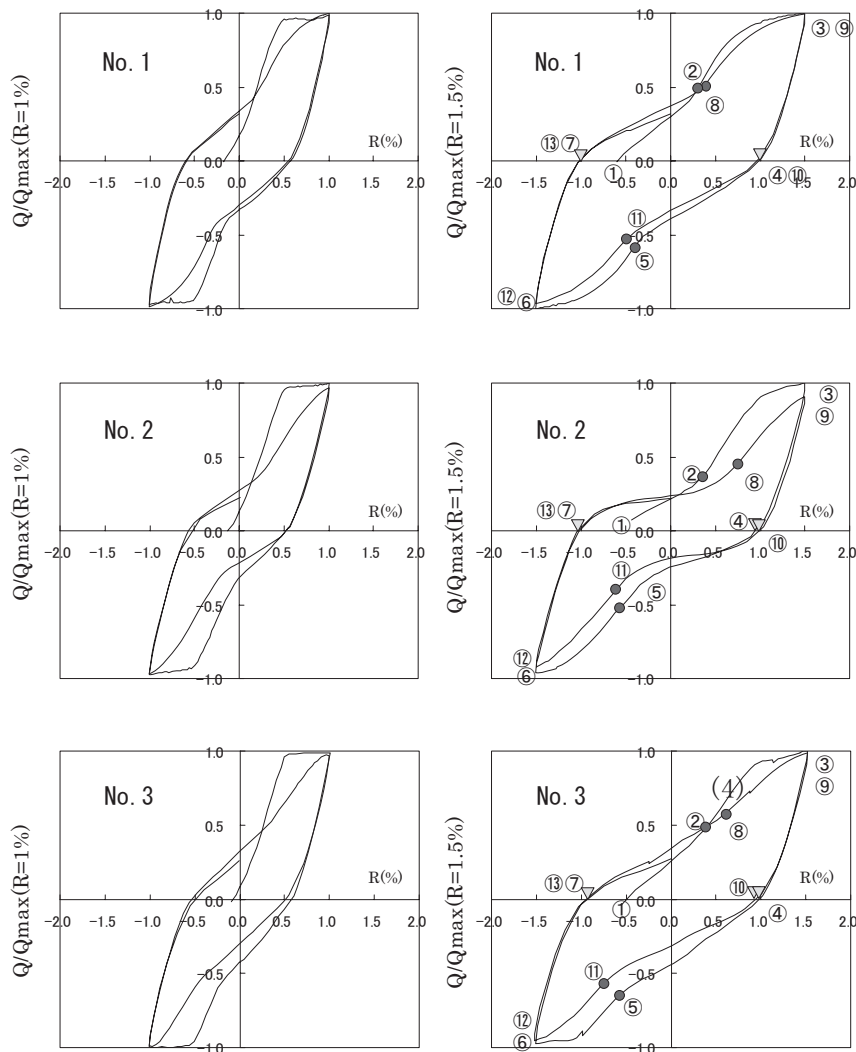

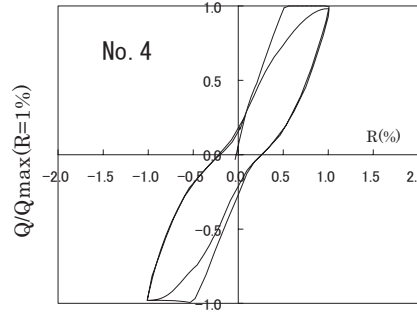

$\mathrm{R}=1 / 100$

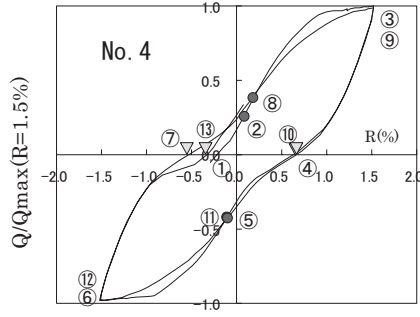

$\mathrm{R}=1 / 66$
図 6 荷重 $(\mathrm{Q} / \mathrm{Qmax})$ 一頂部部材角 $(R)$ 関係

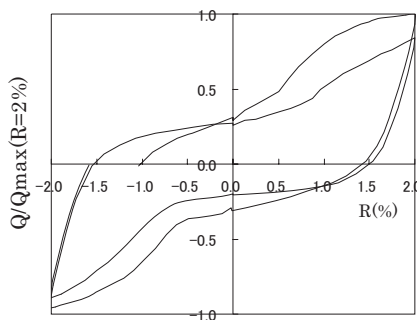

No. $1 \mathrm{R}=1 / 50$

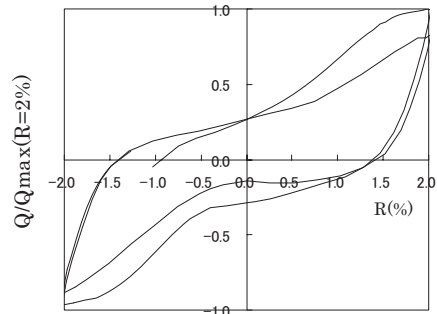

No. $3 \mathrm{R}=1 / 50$
図 7 荷重 $(\mathrm{Q} / \mathrm{Qmax})$ 一頂部部材角 $(\mathrm{R})$ 関係

ピーク時の壁脚部鉛直変位を $\delta_{V p(R i)}(R i ;$ 変形角 $)$ 、水平力ゼロ時の

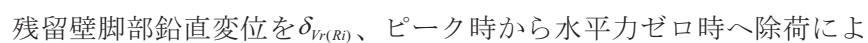
つて戻る鉛直変位を $\delta_{V d(R i)}$ と定義すると、各変形段階において壁脚部 鉛直変位の関係は式(1) と書くことができる。

$$
\delta_{V p(R i)}=\delta_{V d(R i)}+\delta_{V r(R i)}
$$

耐震壁が圧縮側柱脚部を回転中心として変形すると仮定すると、 壁脚部の回転角 $\theta$ は式 (2) で表すことができるので、引張側柱の伸び 量 $\delta_{V T(R i)}$ は式 (3) で推定できる。
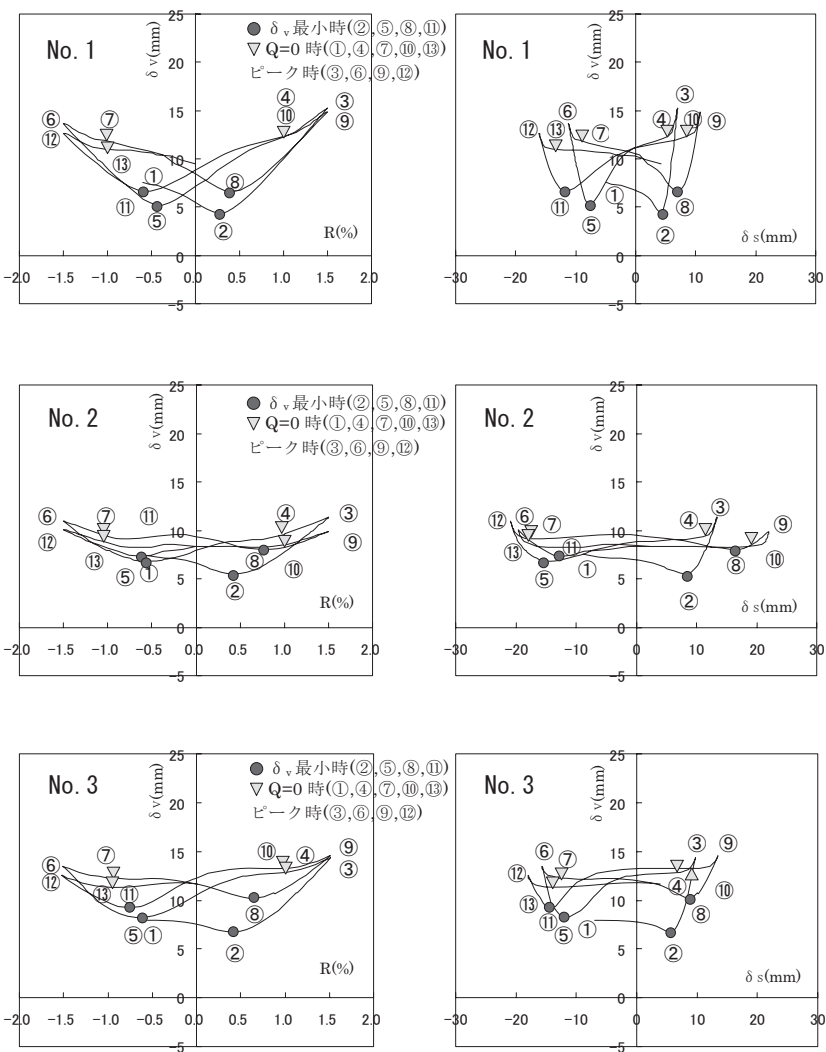

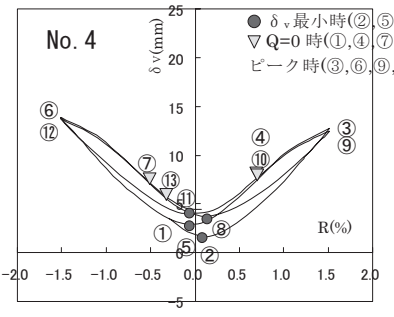

図 $8 \delta_{v}-R$ 関係 $(R=1 / 66)$

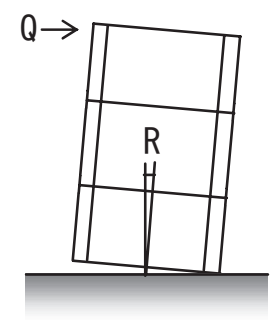

図 $10 \delta_{\mathrm{v}}$ の算出方法

$$
\begin{aligned}
& R_{(R i)}=\theta_{(R i)} \\
& \delta_{V T(R i)}=\theta_{(R i)} \cdot \ell \mathrm{W}
\end{aligned}
$$

ここで、 $R_{(R i)}$ : 頂部部材角 $(\mathrm{rad}) 、 \theta_{(R i)}$ : 壁脚部回転角 $(\mathrm{rad}) 、 \ell \mathrm{W}$ : 耐震壁の両側柱中心間距離 $(\mathrm{mm})$ （本実験の場合、2,000mm）、なお $R i$ は各変形角段階を意味する。

$\mathrm{R}=1 / 200$ 以降の変形では、壁脚部鉛直変位平均值は水平力ゼロ時で 浮上った状態となる。ただし、ピーク時の圧縮側脚部鉛直直変位は 正負加力ともに $\delta_{V 1} \fallingdotseq 0, \delta_{V 2} \fallingdotseq 0(\mathrm{~mm})$ と考えると、式 (1)の $\delta_{V p(R i)}$ は左右 壁脚部鉛直変位の平均值なので式 (4)で表すことができる。

$\delta_{V p_{(R i)}}=\left(\delta_{V T(R i)}+0\right) / 2=\delta_{V T(R i)} / 2$ 


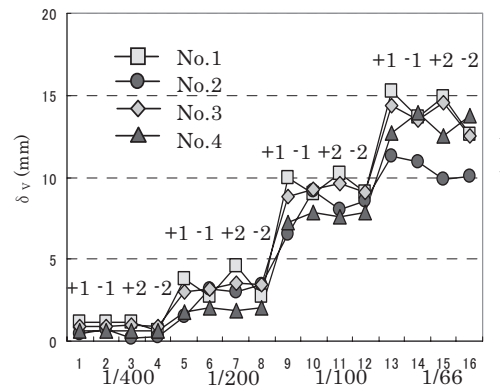

(a) ピーク時の $\delta_{\mathrm{v}}$ 推移

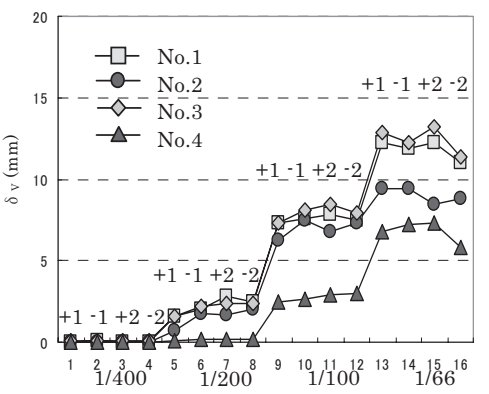

(b) 水平荷重ゼロ時の $\delta_{\mathrm{V}}$ 推移
図 $11 \delta_{\mathrm{v}}$ の推移

残留壁脚部鉛直変位 $\delta_{V_{r}(R)}$ を求めるには、水平力除荷による戻り変 形量 $\delta_{V d(R i)}$ の評価法を定義する必要がある。このピーク時から戻る鉛 直変形量 $\delta_{V d(R i)}$ は、引張側鉛直変形がピーク時から除荷によって水平 力ゼロ時へ戻る鉛直変位の $1 / 2$ (左右の平均) となる。つまり、 $\delta_{V d(R i)}$ は、引張側柱の鉛直変位の戻り量を評価することにより求められる。 また、 $\delta_{V d(R i)}$ は引張側柱の鉛直変位であるから引張側鉄筋の歪で表す ことができるので、ピーク時から水平力ゼロ時までの鉄筋歪の戻り 量を式(5)で表すとする。

$$
\varepsilon_{d(R i)}=\varepsilon_{y(R y)}+\varepsilon_{N(R i)}
$$

ここに、 $\varepsilon_{d(R i)}$ : 変形角Riのピーク時から水平力ゼロまでの引張鉄筋 戻る歪量 $(\mu) 、 \varepsilon_{y(R y)}:$ 弾性戻り量とし降伏変形時の戻る歪量 $(\mu)$ で 式 $(6)$ の值 $\left(R y\right.$ は降伏時の変形角) とする、 $\varepsilon_{N(R i)}$ : 引張側軸方向鉄筋に 作用する軸方向力により戻る歪量 $(\mu)$ 。

$$
\begin{array}{ll}
\varepsilon_{y_{(R i y)}}=\varepsilon_{d(R=1 / 400)} & (\text { No.1,2,3) } \\
\varepsilon_{y_{(R i y)}}=\varepsilon_{d(R=1 / 200)} & \text { (No.4) }
\end{array}
$$

式(5)の関係を降伏後 $R=1 / 50$ まで歪計測が可能であった鉄筋につ いて調査した結果、概ね式(7)の関係になることが分かった。

$$
\varepsilon_{N(R i)}=\varepsilon_{d(R y)}-\varepsilon_{y(R y)}=\frac{N / 2}{\sum a_{C} \cdot E_{S} / 4}
$$

ここに、 $N$ : 軸方向力 $(\mathrm{N}) 、 \sum a_{C}$ : 柱軸方向筋断面積 $\left(\mathrm{mm}^{2}\right) 、 E_{S}:$ 柱 軸方向筋のヤング係数 $\left(\mathrm{N} / \mathrm{mm}^{2}\right)$ 。

降伏機構分離型では柱内の付着を切っているので、歪を積分する ことにより引張側鉛直変位を算出することができる。式(5)に式 (6) 及び式 (7)を代入し、柱軸変形量で表すと式(8)となる。

$$
\int \varepsilon_{d(R i)}=\int_{0}^{\mathrm{B}} \varepsilon_{y(R y)}+\int_{0}^{\mathrm{B}} \varepsilon_{N(R i)}=\varepsilon_{d(R y)} \cdot \ell_{B A R}+\frac{N / 2}{\sum a_{C} \cdot E s / 4} \cdot \ell_{B A R}
$$

ここで、 $\ell_{B A R}$ は塑性化する軸方向筋の長さ $(\mathrm{mm})$ であり、本実験の 場合、接合部筋のアンボンド長さに相当する。

壁脚部鉛直変位は引張側柱の戻り量の $1 / 2$ となるので、 $\delta_{V d(R)}$ は式 (9)で表すことができる。

$$
\delta_{V d(R i)}=\frac{1}{2}\left(\delta_{V d(R y)}+\frac{N / 2}{\sum a_{C} \cdot E S / 4} \cdot \ell_{B A R}\right)
$$

水平力ゼロ時の残留壁脚部鉛直変位 $\delta_{V_{r(R i)}}$ は、式(4) 及び式 (9) を式 (1)に代入し、式(10)が導かれる。

$$
\delta_{V r(R i)}=\frac{1}{2} \delta_{V \mathrm{~T}(R i)}-\frac{1}{2}\left(\delta_{V d(R y)}+\frac{N / 2}{\sum a_{C} \cdot E s / 4} \cdot \ell_{B A R}\right)
$$

図12に水平力ゼロ時の残留鉛直変位に関する実験值と式(10)によ り算出した計算值の比較を示す。スリップ変形が大きくなったNo. 2 のR=1/66サイクルを除きNo. 1, 2, 3, 4の全てについて計算値は実験值

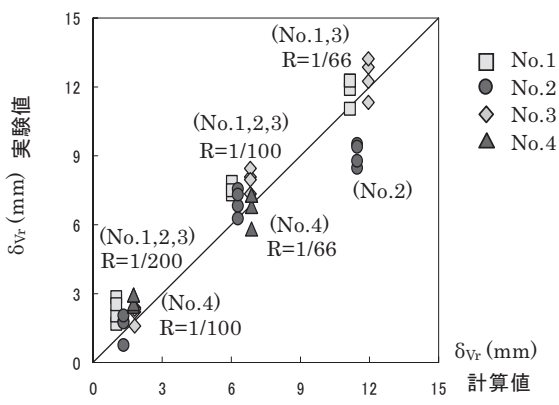

図 12 水平荷重ゼロ時鉛直変形の実験值・計算值の比較
にほぼ等しい。軸方向力が大きいNo.4の残留鉛直変位は、No. 1, 2, 3 に対して1つ前の変形段階の鉛直変位にほぼ等しくなった。

\section{5. 壁脚部せん断剛性と曲げ剛性}

水平荷重ゼロ時での壁脚部鉛直変位は図11のように推移するので、 軸力比が高いNo. 4を除き、 $\mathrm{R}=1 / 200$ 以降のサイクルで浮上った状態と なる。壁脚部が浮上った状態での壁脚部せん断剛性と曲げ降伏後の 耐震壁全体の曲げ剛性との比較から、スリップ現象が発生するとき の剛性比の定量的な評価を試みる。

\section{1 壁脚部せん断剛性}

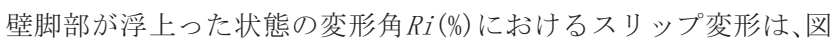
13に示すせん断抵抗機構でモデル化する。図13は壁脚部に残留鉛直 変位 $\delta_{V_{r}}$ が生じ浮上ったときの軸方向筋とダボ筋の応力と変形状態 である。軸方向筋は反曲点位置を中央とする逆対称の応力・変形状 態とし、ダボ筋は引張抵抗がないアンボンド側でせん断力だけを伝 達する機構を仮定する。柱内ダボ筋のアンボンド側埋込み長さは $5.7 \mathrm{~d}(\phi 35) \sim 11.5 \mathrm{~d}$ (D13) であり抜け出すことから、アンボンド側で はコンクリートへのせん断伝達のみを考慮し曲げ抵抗は無視するこ ととした。壁脚部は浮上るのでコンクリート同士のかみあいによる 摩擦抵抗はなく、せん断抵抗は軸方向鉄筋の曲げ抵抗・ダボ抵抗だ けとなる。

軸方向筋及びダボ筋の1本あたりの剛性は式 (11) 及び式 (12) とな る。壁脚部が浮上った状態における壁脚部せん断剛性は、 $m_{B}$ 本の柱 内軸方向筋と $m_{D}$ 本のダボ筋から構成されるので式(13)で表すことが できる。式(11)及び式(12)の誘導を付録 1 に示す。

$$
\begin{array}{ll}
k_{B(R i)}=\frac{1.5 E_{S} I_{S} \beta^{3}}{\left(1+0.5 \beta \delta_{V r(R i)}\right)^{3}+0.5} & (\text { 柱内軸方向筋) } \\
k_{D(R i)}=\frac{3 E_{S} I_{S} \beta^{3}}{\left(1+\beta \delta_{V r(R i)}\right)^{3}+0.5} & \text { (ダボ笳) } \\
K_{S(R i)}=m_{B} k_{B(R i)}+m_{D} k_{D(R i)} &
\end{array}
$$

ここに $K_{S(R i)}$ : 変形角Ri $(\%)$ 時における壁脚部せん断剛性 $(\mathrm{N} / \mathrm{mm})$ 、 $k_{B(R i)}$ : 変形角 $R i(\%)$ 時における軸方向鉄筋の剛性 $(\mathrm{N} / \mathrm{mm}) 、 k_{D(R i)}$ : 変形 角 Ri (\%) 時におけるダボ筋の剛性 $(\mathrm{N} / \mathrm{mm})$ 、またコンクリートと鉄筋の $\beta$ は式 (14)で与えられる特性值 $(1 / \mathrm{mm})$ である。この $\beta$ の算出に用い るコンクリート水平反力係数 $k c(1 / \mathrm{mm})$ には中野ら ${ }^{13)}$ の実験による提 案式(15)を用いた。

$$
\begin{aligned}
& \beta=\sqrt[4]{\frac{k c \cdot d_{B}}{4 E_{S} \cdot I_{S}}} \\
& k c=55\left(\frac{E_{C} \cdot \sigma_{\mathrm{B}}}{E_{S} \cdot \delta_{S 0}}\right)^{3 / 4}
\end{aligned}
$$




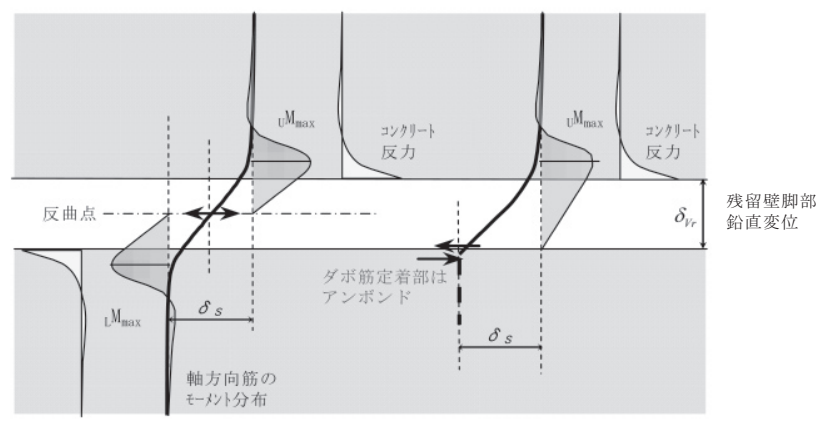

(a) 軸方向筋の抵抗機構

(b) ダボ筋の抵抗機構

図 13 壁脚部せん断抵抗機構 $(R i$ 時)

ここで、 $E_{C}$ : コンクリートのヤング係数 $\left(\mathrm{N} / \mathrm{mm}^{2}\right) 、 \sigma_{B}$ : コンクリ

一トの圧縮強度 $\left(\mathrm{N} / \mathrm{mm}^{2}\right) 、 \delta_{S 0}$ : 軸方向筋あるいはダボ筋のコンクリ

一ト境界面における水平変位 $(\mathrm{mm})$ である。式(15) は純せん断実験に おける実験式であるが、コンクリート強度・鉄筋強度・鉄筋径に依存 しないだけでなく、弾性域に限らず非線形性を考慮できる ${ }^{13)}$ ので、 弾性支承ばり理論から誘導した式(13) を本研究における曲げ降伏後 の耐震壁脚部せん断剛性に適用できると判断した。

式(15)を用いて kcを算出するためにはコンクリート境界面におけ る鉄筋の水平変位 $\delta_{S 0}$ を設定する必要がある。 $\delta_{S 0}$ は残留壁脚部鉛直 変位及び特性值 $\beta$ の関数なので、壁脚部せん断変形との関係づける ことにより推定することができる。本実験の場合、変形角Riにおけ る壁脚部スリップ変形量 $\delta_{S(R i)}$ と $\delta_{S 0}$ の関係は式 $(16)($ 付録 2 ) となる。

$$
\delta_{S 0(R i)}=\delta_{S(R i)} / 3
$$

全変形量 $\delta_{T(R i)}$ に対するスリップ変形量 $\delta_{S(R i)}$ の割合を $\alpha$ とると、 図5から $\alpha$ を仮定し式(16)を書き換えると式(17) となる。

$$
\begin{aligned}
& \delta_{S 0(R i)}=\alpha \cdot \delta_{T(R i)} / 3 \\
& \text { ただし、 } \\
& \mathrm{R}=1 / 200 \text { のとき } \alpha=0.1 \\
& \mathrm{R}=1 / 100 \text { のとき } \alpha=0.2 \\
& \mathrm{R}=1 / 66 \text { のとき } \alpha=0.3 \\
& \mathrm{R}=1 / 50 \text { のとき } \alpha=0.4
\end{aligned}
$$

以上、式(14)、(15)、(17)から $\beta$ を算出し、式(10)より残留壁脚部 鉛直変位を算出することにより、各変形段階のせん断剛性が式 (11) 〜(13)を用いて算出できる。

本検討では曲げ降伏後の耐震壁におけるせん断抵抗であること、 水平荷重ゼロ時でも引張側柱軸筋の伸びは戻っていないこと、を踏 まえ軸方向筋のうち、圧縮側となる柱軸筋( 接合部筋と曲 げ補強筋、 No. 3ではダボ筋を含む) 及び壁ダボ筋（壁縦筋の $1 / 2$ 相当を配筋）に より評価する。

柱内軸方向筋（接合部筋、曲げ補強筋）は、 $\mathrm{R}=1 / 200$ 以降の繰返し で引張降伏が進み弾性範囲ではない。ただし、図5からスリップ変形 の全体変形量に占める割合は、R=1/200以降、変形量の増加に比例し て漸次増加する傾向がある。この現象から軸方向筋は、弾性範囲に はないが定量的な傾向を把握するため、本論では鉄筋の弾性時ヤン

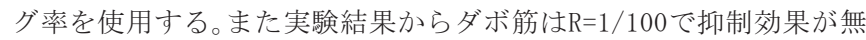
くなるので、式(12)の $\mathrm{R}=1 / 100$ 以降の剛性を0.01倍とした。

\section{2 壁脚部曲げ断剛性}

耐震壁全体の曲げ剛性は、壁脚部が浮上った状態を想定して算出 する。1階部分は接合部筋及び曲げ補強筋の断面積による壁中心の断
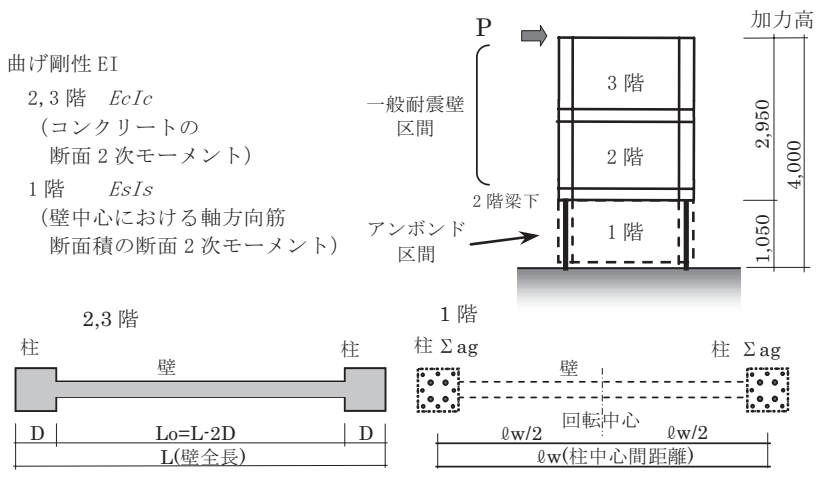

図 14 曲げ剛性算出モデル化

面2次モーメント、2,3階はコンクリート断面から算出される断面 2 次モーメントでモデル化する。図14に曲げ剛性算出モデルを示す。

図14に示したように耐震壁は変断面で構成される片持ち梁と同じ であるからMohrの定理を用いて耐震壁頂部の変形を求め算出した。 その結果、耐震壁の曲げ剛性は式(18)で表せる。

$$
K_{M(R i)}=1 /\left(\frac{h_{1}{ }^{2} h_{2}+h_{1} h_{2}{ }^{2}+h_{1}{ }^{3} / 3}{E_{S} I_{S}}+\frac{h_{2}{ }^{3}}{3 E_{C} I_{C}}\right)
$$

ここで、 $K_{M(R i)}$ : 変形角Ri $(\%)$ 時における曲げ剛性 $(\mathrm{N} / \mathrm{mm}) 、 E S$ : 軸方 向筋断面積のヤング係数 $\left(\mathrm{N} / \mathrm{mm}^{2}\right) 、 I_{S}: 1$ 階の鉄筋断面積で算出される 断面2次モーメント $\left(\mathrm{mm}^{4}\right) 、 E c$ : コンクリートのヤング係数 $\left(\mathrm{N} / \mathrm{mm}^{2}\right)$ 、 $I c$ ：耐震壁コンクリート断面の断面2次モーメント、 $h 1: 1$ 階アンボ ンド区間長さ $(1,050 \mathrm{~mm}) 、 h 2$ : 壁全高さ $(4,000 \mathrm{~mm})$ からアンボンド区 間を引いた高さ $(2,050 \mathrm{~mm})$ 。式 (18)には変形角Riに伴う関数がないの で、変形角に関わらず一定值となる。

\section{6. 降伏機構分離型耐震壁の壁脚部せん断剛性と曲げ剛性の比較}

4 ・ 5 章で提案した壁脚部鉛直変位の推定及びせん断剛性の計算 值と曲げ岡性を $\mathrm{R}=1 / 200$ 以降の変形に対して比較検討する。

\begin{tabular}{|c|c|c|c|c|c|}
\hline & & $\begin{array}{r}\delta_{\mathrm{Vr}} \\
(\mathrm{mm})\end{array}$ & $\begin{array}{r}\delta_{\mathrm{s} 0} \\
(\mathrm{~mm})\end{array}$ & $\begin{array}{c}\mathrm{K}_{\mathrm{S}} \\
(\mathrm{kN} / \mathrm{mm})\end{array}$ & $\mathrm{K}_{\mathrm{M}} / \mathrm{K}_{\mathrm{S}}$ \\
\hline 8 & No.1 & 1.0 & \multirow{4}{*}{0.67} & 183.7 & $\overline{0.20}$ \\
\hline i & No.2 & 1.3 & & 174.9 & 0.22 \\
\hline III & No.3 & 1.8 & & 233.5 & 0.17 \\
\hline$\check{\check{x}}$ & No.4 & 0.0 & & 289.9 & 0.14 \\
\hline 8 & No.1 & 6.0 & \multirow{4}{*}{2.67} & $\begin{array}{l}67.3 \\
\end{array}$ & 0.56 \\
\hline & No.2 & 6.3 & & 66.7 & 0.59 \\
\hline$\pi$ & No.3 & 6.8 & & 77.0 & 0.53 \\
\hline$\check{q}$ & No.4 & 1.7 & & 118.7 & 0.34 \\
\hline & No.1 & 11.2 & \multirow{4}{*}{6.06} & 39.3 & 0.96 \\
\hline 0 & No.2 & 11.5 & & 37.9 & 1.03 \\
\hline$\pi$ & No.3 & 12.0 & & 43.7 & 0.93 \\
\hline & No.4 & 6.9 & & 64.7 & 0.62 \\
\hline 0 & No.1 & 16.0 & \multirow{4}{*}{10.67} & 26.9 & 1.40 \\
\hline 5 & No.2 & 16.3 & & 25.4 & 1.54 \\
\hline II & No.3 & 16.8 & & 29.3 & 1.39 \\
\hline & No.4 & 11.7 & & 42.3 & 0.95 \\
\hline
\end{tabular}

表 2 に曲げ剛性計算結果を、また表 3 に $\mathrm{R}=1 / 200$ 以降の各変形段階に おけるせん断剛性計算結果と曲げ剛性との比を示す。

水平荷重ゼロ時におけるせん断剛性の変形角による推移を図15に

表 2 曲げ剛性計算結果

\begin{tabular}{|c|c|c:c|c:c:c|}
\hline & $\begin{array}{c}\sum \text { ag } \\
\left(\mathrm{mm}^{2}\right)\end{array}$ & $\begin{array}{c}\text { Es } \\
\left(\mathrm{kN} / \mathrm{mm}^{2}\right)\end{array}$ & $\begin{array}{c}\text { Is } \\
\left(\times 10^{9} \mathrm{~mm}^{4}\right)\end{array}$ & $\begin{array}{c}\text { Ec } \\
\left(\mathrm{kN} / \mathrm{mm}^{2}\right)\end{array}$ & $\begin{array}{c}\text { Ic } \\
\left(\times 10^{11} \mathrm{~mm}^{4}\right)\end{array}$ & $\begin{array}{c}\mathrm{K}_{\mathrm{M}} \\
(\mathrm{kN} / \mathrm{mm})\end{array}$ \\
\hline \hline No.1 & 1548 & 171 & 3.10 & 21.9 & 1.61 & 37.7 \\
No.2 & 1524 & 182 & 3.05 & 20.6 & 1.61 & 39.1 \\
No.3 & 1524 & 189 & 3.05 & 22.7 & 1.61 & 40.8 \\
No.4 & 1524 & 182 & 3.05 & 27.7 & 1.61 & 40.1 \\
\hline
\end{tabular}

表 3 せ几断剛性計算結果

注1） $\mathrm{R}=1 / 200$ No. 4 は浮上りがないので $\delta_{V r}=0$ とした 注2） $\square$ は、 $\mathrm{K}_{\mathrm{M}} / \mathrm{K}_{\mathrm{S}}>1.0$ 以上 
示す。変形角の増大に伴い残留壁脚部鉛直変位 (浮上り量) が大きく なり、それを要因とするせん断剛性が低下していく現象が計算でも 認められる。軸方向筋から算定したせん断剛性が曲げ剛性よりも小 さくなると、スリップ現象が顕著になると考えられる。荷重一変形 曲線でスリップ現象が現れたNo. 2のR=1/66、No. 1,3のR=1/50におけ る $K_{M} / K_{S}$ の比は1.0を超えている。軸方向力が高いNo.4については、 スリップ現象よりも高軸力による影響で圧縮側柱と壁との境界に縦 割れが発生したことが破壊要因であるため、 $K_{M} / K_{S}$ の比が $\mathrm{R}=1 / 50$ でも1.0を下回っている。

上記の比に関する傾向を言い換えると、R=1/50でスリップ現象が 卓越しないようにするには、 $K_{M} / K_{S}$ の值を制御すれば復元力特性 に富んだ耐震壁とすることが可能であると考えられる。No. 1 やNo. 3 はR $=1 / 66$ で $K_{M} / K_{S}$ が1.0未満であるが繰返しにより若干せん断変 形が増加している。このことから $K_{M} / K_{S}$ は余裕を見て 0.9 未満にす ることが望ましいと思わ杖。

例として、No. 1 からNo. 4がR=1/50の変形段階でもスリップ発生を 抑える改善方法を表4に示寸。改善内容は、実現可能な範囲であり、 スリップ現象を抑制できる可能性が高いと言える。特にコンクリー 卜強度を高強度化することは、コンクリートの水平反力係数を高め ることに繋がるのでスリップ抑制効果が高い。

曲げ剛性と壁脚部せん断剛性を比較することにより、降伏機構分 離型耐震壁の壁脚部スリップ現象を予測できることを示した。ただ し、実験の現象と計算值からの予測を比較検討できた降伏機構分離 型耐震壁の試験体は本研究の 4 体である。本評価方法を普遍的にする にあたってはさらなる検討が望まれる。

\section{7. まとめ}

降伏機構分離型耐震壁のスリップ現象を詳細に検討した結果、以

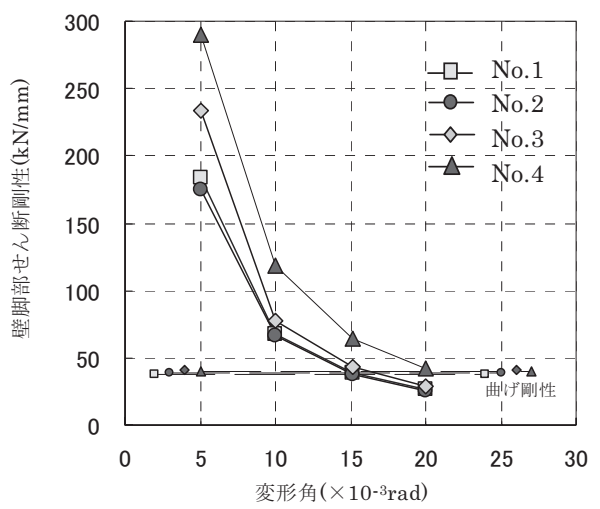

図 15 水平荷重ゼロ時スリップ岡性の推移

表 4 スリップ現象抑制方法の例

\begin{tabular}{|c|c|c|c|c|c|}
\hline & \multirow[b]{2}{*}{ 改善内容 } & \multicolumn{2}{|c|}{ 改善前 } & \multicolumn{2}{|c|}{ 改善後 } \\
\hline & & \begin{tabular}{|c|}
$\mathrm{K}_{\mathrm{S}}$ \\
$(\mathrm{kN} / \mathrm{mm})$ \\
\end{tabular} & $\mathrm{K}_{\mathrm{M}}-\mathrm{K}_{\mathrm{S}}$ & $\begin{array}{c}\mathrm{K}_{\mathrm{s}} \\
(\mathrm{kN} / \mathrm{mm}) \\
\end{array}$ & $\mathrm{K}_{\mathrm{M}} / \mathrm{K}_{\mathrm{S}}$ \\
\hline No.1 & $\sigma_{\mathrm{B}}\left(\mathrm{N} / \mathrm{mm}^{2}\right): 30.4 \Rightarrow 60.0$ & 26.9 & 1.40 & 45.2 & 0.83 \\
\hline No.2 & $\begin{array}{l}\sigma_{\mathrm{B}}\left(\mathrm{N} / \mathrm{mm}^{2}\right): 27.0 \Rightarrow 60.0 \\
\text { 柱内ダボ筋 : 無し } \Rightarrow 2-\mathrm{D} 32(\mathrm{SD} 490)\end{array}$ & 25.4 & 1.54 & 46.3 & 0.84 \\
\hline No.3 & $\sigma_{B}\left(\mathrm{~N} / \mathrm{mm}^{2}\right): 32.6 \Rightarrow 60.0$ & 29.3 & 1.39 & 45.6 & 0.89 \\
\hline No.4 & $\sigma_{B}\left(\mathrm{~N} / \mathrm{mm}^{2}\right): 44.6 \Rightarrow 60.0$ & 42.3 & 0.95 & 52.9 & 0.76 \\
\hline
\end{tabular}

下の知見が得られた。

1) 変形角の増大に伴い壁脚部鉿直変位は大きくなり、浮上った鉛 直変位は水平荷重ゼロ時でも戻らないため、スリップ変形が生 じやすくなる。スリップ変形量が全体変形量の約 3 割になると 荷重変形曲線上にスリップ現象が現れ、その影響により等価粘 性減衰定数が減少する傾向が認められた。

2 ) 水平荷重ゼロ時の残留壁脚部鉛直変位は、軸方向鉄筋量、軸方 向力、及び除荷時における軸方向筋の見かけの塑性化を考虑す ることにより定量的に推定することができる。

3 ) 壁脚部せん断剛性は、浮上った状態の壁脚部界面における軸方 向筋をコンクリート内で弾性支承ばりでモデル化した一般解 を利用して推定できる。また、曲げ剛性はアンボンド区間を鉄 筋のみの $E I$ 、一般耐震壁部分をコンクリート断面の $E I$ でモデル 化することにより評価できる。

4 ）壁脚部せん断剛性が耐震壁全体の曲げ剛性よりも大きければ、 繰返し載荷によるスリップ変形が卓越する現象は抑制できる 可能性が高い。

5 ）壁脚部せん断剛性の定量的評価が可能となったので、要求変形 角までスリップ現象を抑制した高勒性型の耐震壁を設計でき る可能性がある。

今後の課題として、本論文で提案した壁脚部せん断剛性評価方法 が従来の曲げ降伏先行型耐震壁におけるスリップ現象の判定に有効 であるかを検討すること、有限要素法などの解析により現象を追跡 すること、連層耐震壁全体の剛性に対する壁脚部せん断剛性の比率 が地震応答に及ぼす影響を検討すること、などが挙げられる。

\section{参考文献}

1) 平石久廣他: 降伏機構分離型鉄筋コンクリート造の開発 (梁の耐震実験), 日本建築学会構造系論文集，No. 580，pp99～104，2004.6

2）平石久廣他: 重衫継ぎ手方式による降伏機構分離型鉄筋コンクリート造の 開発，日本建築学会構造系論文集，No. 592，pp159～165，2005.6

3) 平石久廣他: 材端部に開孔を有する降伏機構分離型鉄筋コンクリート造梁 の開発，日本建築学会構造系論文集，No. 596，pp95～100，2005. 10

4）勅使川原正臣，楠浩一，江藤博文，野口和也：鉄筋コンクリート構造の接 合技術に関する研究（その 1, その 2) , 日本建築学会大会学術講演梗概 集, C-2 分冊, pp193〜 196, 2003. 9

5）勅使川原正臣，楠浩一，江藤博文，野口和也：鉄筋コンクリート構造の接 合技術に関する研究（その 3 ，その 4)，日本建築学会大会学術講演梗概 集、C-2 分冊、pp343-346、2004.8

6）勅使川原正臣，平石久廣，都祭弘幸，野口和也，飯島康仁：降伏機構分離 型鉄筋コンクリート造部連層耐震壁の履歴性状, 日本建築学会構造系論文 集, No. 580, pp137〜 143，2005. 7

7）都祭弘幸, 栜使川原正臣, 平石久廣, 野口和也 : 降伏機構分離型鉄筋コン クリート造耐震壁のスリップ変形制御方法に関する研究, 日本建築学会構 造系論文集，No. 614，pp99〜106，2007.4

8）望月重，槇谷栄次，永坂具也：壁式プレキャスト構造鉛直接合部のせん断 耐力, 日本建築学会構造系論文報告集, No. 424, pp11 22, 1991.6

9）小川祥平，槇谷栄次，謝爽：接合幅を有するプレキャスト部材接合部ダウ エル筋のせん断伝達, コンクリート工学年次論文報告集, Vol. 16, No. 2, pp817〜822, 1994

10）大西昭徳，槇谷栄次，謝爽：プレキャスト鉄筋コンクリート部材接合面 におけるせん断伝達機構に関する研究, コンクリート工学年次論文報告集, Vol. 18, No. 2, pp1151〜1156, 1996

11）小西伸哉，槇谷栄次，謝爽，伊藤嘉則：高強度材料を用いた $\mathrm{PCa}$ 構造接 合面におけるせん断伝達挙動に関する研究, コンクリート工学年次論文報 告集, Vol. 19, No. 2, pp1317〜1322， 1997

12）大淵英夫，鈴木基晴，南尚吾，中野克彦，松崎育弘：ずれ変形を考慮し たプレキャスト部材接合面におけるせん断伝達に関する研究, 日本建築学 会構造論文報告集，第 491 号, pp97-104, 1997.1

13）中野克彦，松崎育弘：プレキャスト $\mathrm{RC}$ 部材接合面におけるせん断抵抗 
要素の耐力累加方法, 日本建築学会構造論文報告集, 第 550 号, pp151-158, 2001.12

14）衣笠秀行, 野村設郎：曲げ降伏後の大変形繰り返し載荷を受ける RC 梁部 材のスリップ域における横方向歪蓄積により発生する破壊のメカニズム, 日本建築学会構造系論文集, No. 538, p147〜 153, 2000. 12

15）黒木光博, 塩原等 : 耐力低下とスリップ性状を考慮した RC 梁部材の復元 力特性モデル, コンクリート工学年次論文報告集, Vol. 29, No. 3, pp193 〜 198, 2007

16）平石久廣, 都祭弘幸, 川島俊一, 井上芳生 : 偏平な付帯柱を有する連層 耐震壁の曲げ降伏後の勒性に関する実験的研究, 日本建築学会構造系論文 集，No. 395，p48〜 59，1989. 1

17）松本和行, 壁谷澤寿海： R C 而震壁の等価粘性減衰, 日本建築学会大会 学術講演梗概集, C-2 分冊, pp273〜274, 1994.9

\section{付録 1 軸方向筋及びダボ筋の剛性}

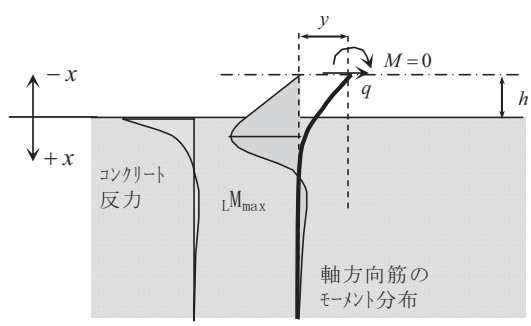

付図 1 壁脚部から突出している鉄筋

図13のせん断抵抗機構は、付図1に示すコンクリートから突出した

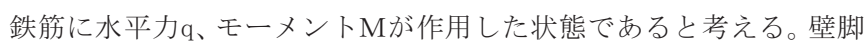
部コンクリート面を堺 $(x=0)$ に上部に突出した軸方向筋の水平変位 をy1(境界面から-x方向)、下部コンクリート内の軸方向筋の水平変 位をy 2 (境界面から+x方向) とし弾性支承ばりの考えを用いると、支 配方程式は突出部で

$$
E_{S} I_{S} \frac{d^{4} y 1}{d x^{4}}=0
$$

またコンクリート内では深さxに関わらず水平反力係数 $k c\left(\mathrm{~N} / \mathrm{mm}^{2}\right)$ が 一定であると仮定し、

$$
E_{S} I_{S} \frac{d^{4} y 2}{d x^{4}}+k c \cdot d_{B} \cdot y 2=0
$$

となる。ここに、 $E_{S}$ : 軸方向筋のヤング係数 $(\mathrm{N} / \mathrm{mm} 2) 、 I_{S}$ : 軸方向筋 の断面2次モーメント $(\mathrm{mm} 4) 、 d_{B}$ : 軸方向筋の径 $(\mathrm{mm})$

式(付1)、式(付2)の一般解はそれぞれ式(付3)、式(付4)で与えら れる。

$$
\begin{aligned}
& y 1=A_{1}+A_{2} x+A_{3} x^{2}+A_{4} x^{3} \\
& y 2=e^{\beta x}\left\{C_{1} \cos \beta x+C_{2} \sin \beta x\right\}+e^{-\beta x}\left\{C_{3} \cos \beta x-C_{4} \sin \beta x\right\}
\end{aligned}
$$

ここに、 $A_{1} \sim A_{2}, C_{1} \sim C_{4}$ は未定積分定数であり、 $\beta$ は式(付5)で表す 特性值 $(1 / \mathrm{mm})$ である。

$$
\beta=\sqrt[4]{\frac{k c \cdot d_{B}}{4 E_{S} \cdot I_{S}}}
$$

簡単のために軸方向筋の径に対して定着長さが半無限であると仮 定すると $C_{1}=C_{2}=0$ となり、さらに式(付3)、式(付4)のxに関する 1 階、2階、3階微分が回転角、モーメント、せん断力となる。軸方向筋 先端 $(\mathrm{x}=-\mathrm{h})$ においてせん断力がq、モーメントが0である条件、さら に $=0$ における式 (付3) ・ (付4) の回転角・せん断力・モーメントの連続 条件から未定積分定数が定まり、式(付6)及び式(付7)となる。

$$
y 1=\frac{q}{6 E_{S} I_{S} \beta^{3}}\left\{\beta^{3} x^{3}+3 \beta^{3} h x^{2}-3(1+2 \beta h) \beta x+3(1+\beta h)\right\}
$$

$$
y 2=\frac{q}{2 E_{S} I_{S} \beta^{3}} e^{-\beta x}\{(1+\beta h) \cos \beta x-\beta h \sin \beta x\}
$$

壁脚部せん断剛性に関係するのはy1であるから、ここからはy1につ いて誘導を進める。

式(付6)に、接合部筋の場合 $x=-h=-0.5 \delta_{V r(R i)}$ 、またダボ筋の場合 $x=-h=-\delta_{V r(R i)}$ を代入し、各鉄筋に単位せん断力 $q=1(\mathrm{~N})$ が作用した ときの残留鉛直変位上下間における軸方向筋の水平変位 $\mathrm{y}_{\mathrm{B}}$ 、ダボ笳 の水平変位 $\mathrm{y}_{\mathrm{D}}$ を求めると、それぞれ式(付 8 ) 及び式(付 9 ) となる。た だし、軸方向筋は反曲点までの変形なので残留壁脚部鉛直変位上下 間の水平変位とするために2倍する。

$$
\begin{aligned}
& y_{B}=\frac{1}{6 E_{S} I_{S} \beta^{3}} \times\left\{2(1+\beta h)^{3}+1\right\} \times 2=\frac{\left(1+0.5 \beta \delta_{V r(R i)}\right)^{3}+0.5}{1.5 E_{S} I_{S} \beta^{3}} \\
& y_{D}=\frac{1}{6 E_{S} I_{S} \beta^{3}} \times\left\{2(1+\beta h)^{3}+1\right\}=\frac{\left(1+\beta \delta_{V r(R i)}\right)^{3}+0.5}{3 E_{S} I_{S} \beta^{3}}
\end{aligned}
$$

以上から軸方向筋及びダボ筋の1本あたりの剛性は式 (付10) 及び 式(付11)となる。

$$
\begin{aligned}
& k_{B(R i)}=\frac{1.5 E_{S} I_{S} \beta^{3}}{\left(1+0.5 \beta \delta_{V r(R i)}\right)^{3}+0.5} \quad(\text { 柱内軸方向筋 }) \\
& \left.k_{D(R i)}=\frac{3 E_{S} I_{S} \beta^{3}}{\left(1+\beta \delta_{V r(R i)}\right)^{3}+0.5} \quad \text { (ダボ笳 }\right)
\end{aligned}
$$

\section{付録 2 コンクリート境界面変位の推定式}

コンクリート境界面の変位 $\delta_{S 0}$ は式(付6) に $x=0, h=0.5 \delta_{V r(R i)}$ を代 入することにより得られる。

$$
\delta_{S 0}=\frac{q}{2 E_{S} I_{S} \beta^{3}}\left(1+0.5 \beta \delta_{V r(R i)}\right)
$$

軸方向筋の水平変位 $\mathrm{y}_{\mathrm{B}}$ と $\delta_{S 0}$ との比は式(付 13 ) となる。

$$
\frac{y_{B}}{\delta_{S 0}}=\frac{2\left(1+0.5 \beta \delta_{V r(R i)}\right)^{3}+1}{\left(1+0.5 \beta \delta_{V r(R i)}\right)}
$$

ここで、 $\beta$ と $\delta_{V r(R i)}$ の範囲を考える。 $\beta$ は本文式 (14) から概ね 20.02 〜0.06の範囲にあり、残留壁脚部鈶直変位は本文式 $(10)$ を用いて $\mathrm{R}=$ 1/200～1/50まで求めると概ね 1 ～ $17 \mathrm{~mm}$ となる。変形段階が小さいと きに $\beta$ は大きくなり $\delta_{V r(R i)}$ は小さくなるので $\delta_{S 0}$ も小さくなる。変形 段階が大きくなると逆の関係となる。この関係を考慮し式(付13)に 上記範囲を代入すると、 $y_{B} / \delta_{S 0}$ の範囲は式(付 14$)$ となる。

$$
y_{B} / \delta_{S 0}=3.0 \sim 3.6
$$

式(付14)の $\mathrm{y}_{\mathrm{B}}$ を壁脚部せん断変形 $\delta_{S(R i)}$ に置き換え、簡単のために 式(付15) とする。

$$
\delta_{S 0(R i)}=\delta_{S(R i)} / 3
$$

